\title{
«Å bli til i det å bli sett». Om sammenvevingen av det etiske og det estetiske $i$ Trondheims minnepark for 22. juli-ofrene
}

\section{Mattias Solli}

NTNU - Norges teknisk-naturvitenskapelige universitet, Institutt for filosofi og religionsvitenskap, Tilknyttet Program for anvendt etikk, mattias.solli@ntnu.no

DOI: http://dx.doi.org/10.5324/eip.v12i1.2426

(cc) BY This is an open access article distributed under the terms of the Creative Commons Attribution 4.0 International License, which permits unrestricted use, distribution, and reproduction in any medium, provided the original author and source are credited.

Artikkelen er en fenomenologisk og hermeneutisk betraktning av Trondheims minnepark for 22. juli-ofrene. Bakgrunnen ligger i et etisk moment av hermeneutisk selvkritikk, som utspilte seg $i$ storsamfunnets reaksjoner på terroren, og som parken må sees $i$ lys av. Artikkelen tar utgangspunkt $i$ at flere av diktene som er slipt inn $i$ minneparkens hvite betong, tematiserer behovet for mellommenneskelig anerkjennelse. Ved hjelp av kunstteoretikeren Bourriaud og filosofene Fichte og Hegel synliggjøres det hvordan dette temaet - mellommenneskelig anerkjennelse - kan sies å vore integrert $i$ parkens helhetlige estetikk. Siste del drøfter ved hjelp av Gadamer hvordan anerkjennelse også er relevant for aktiviteten med å gå omkring og lese diktene i parken. Til sammen belyser artikkelen hvordan minneparken utgjør en sammenveving av det etiske og det estetiske, og hvordan ordet minne her har to betydninger. Med parken minnes vi ofrene for terroren $i$ betydningen kollektiv hukommelse, eller in memoriam. Samtidig blir vi påminnet vår evne til å voere $i$ relasjon med andre mennesker, og til å vokse $i$ relasjonelt samspill. Den siste betydningen er filosofisk, og spiller på betydningen gjenerindring (gresk: anamnesis).

Nøkkelord: hermeneutisk selvkritikk, anerkjennelse, deltakelse, hverdagslighet, lesning

English summary: "Becoming fully oneself by being seen." On the connection between ethics and aesthetics in Trondheim's Memorial Park for the July 22 victims

This article presents a phenomenological and hermeneutical consideration of Trondheim's Memorial Park for the July 22 victims. The background evolves in an ethical and hermeneutical form of self-criticism, which emerged in Norway in the public reactions to the terror. The article observes the fact that several of the poems embedded in the white concrete of the Memorial Park promote the need for interpersonal recognition. Through considering ideas of Bourriaud, Fichte, and Hegel, the author demonstrates how this very theme of interpersonal 
recognition is integrated into the park's overall aesthetics. The author considers how recognition is also relevant to the activity of reading the poems in the park through evoking Gadamer's philosophical hermeneutics. In sum, the article demonstrates how the Memorial Park constitutes a joining of the ethical and aesthetic dimensions and how the word memorial [Norwegian: minne] here gains two meanings. In the park we remember the victims of the terror in the sense of collective memory, or in memoriam. At the same time, we are reminded of our ability to be in relationship with other people and to grow in relational interaction. The latter sense is philosophical and draws on the meaning of recollection (Greek: anamnesis).

Keywords: hermeneutical self-criticism, recognition, participation, everyday life, reading

\section{Terra Incognita. Grusomhetens hermeneutiske oppgave}

Midt i Trondheim sentrum ligger det en park som minnes de 77 mennesker som ble drept i terroren 22. juli 2011. Parken er kalt Terra Incognita - Den hvite plassen, og er utformet av Marianne Levinsen og Anders Krüger. Den er i marmorlignende betong, og former et goldt og dødt landskap, men består også av «øyer» med blomsterbed, benker og et rundt basseng med 77 lys i. En gammel bøk står opp av det hvite materialet. Andre store trær står i og rundt parken. I steinformasjonene er det slipt inn utdrag fra forskjellige dikt, utdrag fra Bibelen, fra en sang og fra en tale som var viktig i offentligheten rett etter hendelsene. På steinene kan man også lese tekster skrevet av ungdommer i Trondheim. Parken er uten inngjerding, og er åpen hele døgnet. Informasjonsplaketten ved parken oppgir navn på fem unge mennesker fra Trøndelag som mistet livet denne julidagen. Plaketten oppgir også at Terra Incognita på gamle kart betegner ukjent jord, og markeres med hvite felter. Det står at terroren var et traume for mange, og en tragedie for hele samfunnet. «Et ukjent territorium åpenbarte seg plutselig i livene våre, $i$ vår felles sosiale og politiske hverdag.»

I et fenomenologisk og hermeneutisk perspektiv, hva vil det si å minnes mennesker på denne måten? Tittelen og beskrivelsen på plaketten treffer godt den særegne fortolkningsoppgaven ${ }^{1}$ som ble gitt $i$ forbindelse med terrorhendelsene. Bomben i Regjeringskvartalet og massakren på Utøya var et anstøt i mer enn én forstand: Terroranstøt og hermeneutisk anstøt gikk sammen på en måte som var ny for oss i Norge. Terroristen artikulerte en evne og vilje til onde handlinger, handlinger som i forkant var reelt sett utenkelig. I ettertid kan vi se at reaksjonene som dominerte offentligheten etter hendelsene, har karakter av hermeneutisk selvkritikk. Det ukjente territoriet som åpenbarte seg (om vi bruker metaforen fra minneparken), var jo ikke et annet sted, men i oss selv - i vår egen kultur. «Hver dag, gjennom et helt år, har vi i fellesskap arbeidet for å gi svar på tre nøkkelspørsmål: Hva skjedde 22/7? Hvorfor skjedde det? Og mer fundamentalt: Hvordan kunne vårt samfunn la dette skje?» skriver Gjørvkommisjonen i 2012 (Gjørv, 2012: 13) Spørsmålene er ikke bare reflektert i en mengde andre bøker (Borchgrevink, 2012; Breivik, 2014; Christensen, 2013; Seierstad, 2013; Vetlesen, 2014), men også i de spontane og folkerettslige reaksjonene på terroren. Der terroristen ville fremme redsel, fremmedfrykt og 
splittelse, ble det heller søkt samhold, verdighet og rettferdighet; først gjennom rosetog og sang i gatene, siden gjennom en av norgeshistoriens mest omfattende rettssaker. I likhet med Gjørv-rapporten kan de spontane og rettslige reaksjonene tolkes som en hermeneutisk besinnelse over grunnlaget $i$ vår kulturelle selvforståelse. For å låne et uttrykk fra Gadamer (2001b: 172): Noe måtte «hjelpe forstanden til å orientere seg» i spørsmålet om hvem vi var som samfunn, og i spørsmålet om hvordan vi skulle gå videre etter slike vanvittige massedrap.

Selv om det er blitt påpekt at det offisielle bildet av det godhetssøkende samfunnet ikke er hele sannheten (Harr \& Partapuoli, 2012), ligger det åpenbart et etisk moment i denne holdningen av selvkritikk. Det er lett å se for seg et samfunn reagere helt annerledes, ikke bare med hevn, lynsjing og drap av morderen, men også med totalt fravær av spørsmål om seg selv. Men som Gadamer sier: Bare den som ser seg selv i sakens egen annethet, kan lære å kjenne både seg selv og det fremmede (Gadamer, 2003: 43). Ja, Gadamer hevder at å forstå seg selv i saken, er primært i enhver forståelsesprosess (Gadamer, 2010a: 299). ${ }^{2}$ Det er det som muliggjør dannelsen av et allment prinsipp som rommer menneskelig forskjellighet, snarere enn å skyve det bort etter forutbestemte oppfatninger. Med andre ord, evnen til å se seg selv i saken er det som muliggjør et dialektisk, pluralistisk og økumenisk fellesskap av nettopp den typen som terroristen ville ramme (Bangstad, 2014). Selv om grunnlaget for selvkritikken utvilsomt var til stede i kulturen før terroren, måtte ikke desto mindre ressursene i det grunnlaget oppdages på nytt. Det gode og konstruktive som tross alt viste seg etter terroren, var enda et ukjent land - et terra incognita - den uhyggelige kvelden 22. juli 2011.

Dette etiske momentet danner bakgrunnen for minneparken i Trondheim. Parken ble til i forlengelsen av storsamfunnets diskursive, spontane og borgerrettslige reaksjoner, og den er i tråd med nasjonale retningslinjer for minnesteder etter 22. juli (Mortensen, 2013). At minneparken faktisk ligger der, er likevel ikke selvsagt. Som vi vet, har utformingen av minnestedene i Oslo og Utstranda (ved Utøya) ført til så mye og så hard diskusjon at et nasjonalt minnested per 2017 fremdeles står urealisert (Heggren, 2017). Kanskje mindre sto på spill i Trondheim, i hvert fall ble ikke diskusjonene like harde og lammende. Også her var det imidlertid folkelig engasjement. Gjennom åpne møter og gruppearbeid på fritiden deltok ungdommer og voksne først med innspill til hvilket finaleutkast som skulle realiseres, dernest i utvelgelsen av hvilke tekster som skulle slipes inn i parkens steinformasjoner (www.trondheim.kommune.no). Dermed kan det etiske momentet vi nettopp bemerket for storsamfunnets del, sies å være vevet sammen med minneparkens estetiske uttrykk. Som subjekter kan vi like eller ikke like resultatet, vi kan synes parken er vellykket eller ikke med hensyn til den funksjon den skal fylle, men uansett må vi forholde oss til at parken uttrykker en kollektiv enighet, både gjennom å finnes, og gjennom sin kunstneriske utforming. Noe står der. Noe har fått retning. Parken minner oss på at et liv etter terroren er mulig - og nødvendig.

\section{Fortolkning og påminnelse}

Hvordan minner parken oss på at et liv etter terroren er mulig og nødvendig? Parken er utvilsomt et minnested i betydningen in memoriam. Vi husker de drepte, de blir en del av vår felles hukommelse. Samtidig er parken åpenbart noe 
mer. Den kan for eksempel også kalles et slags fortolkningsarbeid, og da endatil i dobbel forstand. I én forstand kan parken sees som en måte terrorhendelsene og spørsmålet om hvem vi er som samfunn, fortsatt bearbeides i det offentlige rom. Det er ikke selvfølgelig at et samfunn bruker et estetisk uttrykk som det vi finner i Trondheim, til å hedre sine drepte. I grell kontrast til parkens nøkterne stil er det lett å tenke seg samfunn som heller ville valgt store statuer med hevede fakler, i stedet for det vi ser her. En annen forstand som parken kan sies å være et fortolkningsarbeid, ligger i det at den ikke gir klare svar, hverken om det ene eller andre. Foruten plakettens sparsomme kontekstualisering gis det ingen bestemte anvisninger for hvordan man skal forstå parkens hvite og golde landskap. Parken bare ligger der, som noe varig og noe estetisk, åpent for subjektiv fortolkning.

Det vil si, ett tema går igjen i flere av diktene som er slipt inn den hvite betongen, nemlig behovet for mellommenneskelig anerkjennelse. La oss lese ett av utdragene, skrevet av Terje Dragseth:

Jeg skriver språket om å bli sett

av sin mor sin far sin bror sin neste

å bli til det å bli sett

skriver jeg

for vi er synlige i vår ensomhet

vi er synlige og elsket

i vår felles ensomhet

Hvorfor er akkurat dette temaet - mellommenneskelig anerkjennelse - så relevant for et 22. juli-minnested? La oss tenke over det. I en viss forstand er dette en tematikk som dreier seg om vår relasjon til de drepte. In memoriam anerkjenner dem som ikke lenger er blant oss. Eller for å parafrasere Dragseth: Vi ser dem som ikke lenger er synlige etter 22. juli, men som likevel fortsatt er elsket av familie, venner og samfunn.

Samtidig, fra et hermeneutisk perspektiv, kan vi også se at tematikken i diktet peker både bakover og framover i tid. Retrospektivt peker den på terroristens oppvekst, som var preget av personlig og systematisk omsorgssvikt (Borchgrevink, 2012; Gjørv, 2012). Den peker også på terroristen som voksen mann, der han av egen fri vilje satte til side grunnleggende menneskeverd hos andre, for sitt eget behov for å bli sett og anerkjent (se Vetlesen, 2014, for filosofisk analyse av gjerningsmannen og hans motiver). I parkens kunstneriske uttrykk ligger det imidlertid også en etisk påminnelse, og den er prospektiv. Diktet minner oss på at vi fra nå av ikke kan tillate at det som engang skjedde med terroristen som barn, skal skje med andre barn. Og det minner oss på at vi ikke må gjøre som terroristen gjorde som voksen, og skape oss om til hensynsløse voldsutøvere. Denne etiske påminnelsen er utvilsomt normativ: Diktet peker mot en fremtid som ikke bare kan, men som må bli. Fremtiden må bli uten den meningsløse og umenneskelige volden som vi så 22. juli, men heller fylt med omsorgsfull, mellommenneskelig anerkjennelse. Hva det vil si filosofisk, vil utdypes i den følgende betraktningen. 


\section{Synliggjoringen av det hverdagslige}

Vi har nå begynt å se hvordan et etisk moment kan sies å være vevet inn $\mathrm{i}$ minneparkens estetiske fremtoning, både med tanke på tilblivelsen av parken og med tematikken i diktene. Hva så med resten av parken? Kan et etisk moment av mellommenneskelig anerkjennelse også sies å være reflektert i parkens mer helhetlige estetikk? Den hvite steinen bare ligger der, treet bare står der, vannbassenget bare åpner opp en mørk sirkel i grunnen. Gjenstandene hviler med en uutgrunnelig tyngde. Samtidig er det rimelig å si at en viss skjønnhet trer frem i parken. Materialbruk, farger, utforming og måten parken generelt responderer på bygningene rundt seg, er verken tilfeldig eller virkningsløs. Kontrastene blir klare: Det livfulle med plantene, trærne og publikum, kjøpesenteret og de andre bygningene rundt parken står ut - på bakgrunn av det golde og livløse. Noe artikulerer seg. Men hva - og hvordan?

Sammenligner vi Terra Incognita med Holocaust-minnestedet i Berlin eller det nasjonale minnestedet som var planlagt ved Utstranda, kalt Memory Wound, er det ingen tvil om at de to sistnevnte er monumentale og katarsis-pregete i en helt annen grad enn det i Trondheim. Mens minnesmerket ved Utstranda var tenkt som rått og nesten brutalt, med en fjellvegg skåret opp i et kraftig snitt, er Terra Incognita nettopp «bare» en park. Det rå og voldsomme uteblir, uten at det dermed mangler av den grunn. For som informasjonsplaketten sier: Parken er ønsket som et kombinert minnested og et byrom for hverdagsliv og sosiale møter. Selv om det utvilsomt er en viss verdighet ved parken i Trondheim, og selv om neppe all oppførsel sømmer seg der, synliggjør parken det hverdagslige - slik Trondheimslivet er for eksempel en onsdag, i firetiden, hvor noen haster hjem fra jobb, mens andre sitter i parken og leser avisen, og barn plasker i bassenget. Eller når det er større anledninger, synliggjør parken hvordan folk møtes i engasjement og livsutfoldelse. Den hverdagslige og livsnære holdningen gjør noe med tingene i parken. Det hvite underlaget, benkene og bassenget gis en slags dobbel karakter av å være uutgrunnelige estetiske gjenstander og hverdagslige ting.

Men hva gjør holdningen med oss som publikummere? Vi nærmer oss spørsmålet ved å studere parken i lys av kunstteoretikeren Bourriaud. Bourriaud, som er kjent for sin såkalte relasjonelle estetikk, interesserer seg særlig for en tendens han finner i kunst etter 1990-årene, som går mot en hverdagslig og deltakerorientert kunstpraksis. Poengene til vår analyse henter vi ved hjelp av hans eksempler (Bourriaud, 2007: 33). I kunstprosjektet Aperto 93 av Rirkrit Tiravanija kan publikum gå fritt omkring en stor kjele som har et brennende propanapparat under seg og campingutstyr strødd rundt. De kan ta vann fra kjelen og tilberede kinesisk, frysetørret suppe som ligger i pappesker. Bourriaud hevder at dette er representativt for nyere kunst, og gjør da et poeng ut av at prosjektet er ubestemmelig i lys av tradisjonelle kategorier som skulptur, installasjon, performance eller sosial aktivisme. Det derimot kunsten tydeliggjør positivt, er momentet av deltakelse og hverdagslighet. Publikum er ikke betraktere av vakre eller betydningsfulle gjenstander, men reelle deltakere i kunstprosjektet. Den nye kunsten synliggjør dermed det relasjonelle - det intersubjektive - for sin egen del, hevder Bourriaud. «Essensen av den kunstneriske praksis ligger [...] i opprettelsen av relasjoner mellom subjektene» (Bourriaud, 2007: 29). Uten å kreve noe i direkte forstand bidrar kunsten med en slags utvendiggjøring av den man er i hverdagslivet. Man stiller seg på en måte 
frem for andre i det man for eksempel strekker armen fram, og lager seg frysetørret suppe innenfor rammen av det kunstneriske uttrykket. Den smått kunstige og samtidig profane konteksten aktualiserer ikke bare erfaringen av å se på kunst, eller av å se på andre mennesker, for den saks skyld, men også av å bli sett. Kunstgjenstandene blir en slags mediering av blikkene. Det direkte, sosiale blikket avlastes. Publikum ser og blir sett via deltakelsen i et felles prosjekt.

Selv om minneparken i Trondheim naturligvis ikke kan kalles kunst i samme forstand som det Bourriaud skriver om, synliggjør eksemplet hans noe ved parkens estetiske uttrykk. Et fellestrekk finnes nemlig i kombinasjonen av deltakelse, hverdagslighet og kunstferdig kontekst. Analogt til suppeeksemplet transformeres den hverdagslige omgangen innenfor det estetisk transformerte byrommet. Relasjonsrommet innsnevres, kan vi si med bakgrunn i Bourriaud. Publikum forholder seg til hverandre via felles deltakelse i det estetiskhverdagslige bruksuttrykket gitt parken som park. For oss er det viktigste poenget den etiske dimensjonen som dermed impliseres. Betraktet med Bourriaud kan nemlig parken - som et hele - nå sies å tydeliggjøre et slags opprinnelig behov for mellommenneskelig anerkjennelse. Gjennom å delta side om side i det estetiserte byrommet gis publikum mulighet til å eksponere, vis-à-vis hverandre, en menneskelig sårbarhet og lengsel etter å bli sett. "[E]ssensen av det sosiale er behovet for anerkjennelse heller enn konkurranse eller vold,» skriver Bourriaud (2007: 32). Det er dette behovet den deltakerorienterte kunsten evner å bringe for dagen, og som også potensielt kan sies å skje med minneparkens utforming. Gjennom den resiproke deltakelsen blir vårt behov for mellommenneskelig anerkjennelse så å si manifest i det ytre - i det intersubjektive, i det konkrete og i det hverdagslige.

\section{Anerkjennelse}

Bourriauds kunstteori er fruktbar for å synliggjøre hvordan det relasjonelle er tydelig for sin egen del i dagens kunstuttrykk. Men ønsker vi å forstå hva som ligger i hans generelle påstand om at anerkjennelse er essensen av det sosiale, må vi gå andre steder. Med det mål om å forstå mer av sammenvevingen av det etiske og estetiske i minneparken utdyper vi derfor påstanden ved å henvise kort til filosofitradisjonen, nærmere bestemt til Fichte og Hegel. ${ }^{3}$ Fichte (1796) introduserer begrepet om anerkjennelse i tradisjonen etter Kant. Han poengterer at vi aldri møter andre mennesker som et begrep eller universelle krav som sådan, men alltid som ett annet menneske, i singulær forstand. Dette bestemte individet står foran meg, med en kropp og et sinn som aldri kan være min eller mitt. Eierskapsforholdet er absolutt. Det tilfaller uvilkårlig den andre å vøere noe annet enn meg. Jeg kan aldri vite om han eller hun har en adekvat forestilling om meg, eller overhodet forholder seg til min eksistens. Dermed står den andre foran meg som en uutgrunnelig fremmedhet - som noe som er prinsipielt utilgjengelig for meg.

Tenker vi med Fichte, er nettopp denne gjensidige fremmedheten noe av det som må anerkjennes i enhver mellommenneskelig relasjon. Det kan vi gjøre gjennom å artikulere for oss selv et universalisert begrep om fremtidig handling. Likevel er det ikke det Fichte interesserer seg mest for, og heller ikke det som vil være mest relevant i vår kontekst. Det interessante og relevante ligger snarere $\mathrm{i}$ det vi kan kalle en minimumsbevegelse av anerkjennelse, som Fichte lokaliserer i 
selve møtet med den andre, og som går forut for enhver kognitiv akt. ${ }^{4}$ Uten at vi behøver å tenke oss frem til noe som helst, ser vi umiddelbart at den andre er et menneske i likhet med oss selv. Eller for å være mer presis: Enten så ser vi det på et øyeblikk, eller så kommer det aldri til å skje (Fichte, 1796: 89). Dersom det skjer, og det er rimelig å tolke Fichte dit hen at det stort sett skjer, så innstiftes det nesten direkte en mellommenneskelig relasjon i møtet mellom to mennesker. Selv om vi altså aldri kan være sikre på at det samme har skjedd hos den andre, så har vi i grunnen alltid allerede anerkjent noe hos vedkommende. Vi har anerkjent at den andre tilhører et menneskelig fellesskap på linje med oss selv. Fichte gir dermed Bourriaud rett: Anerkjennelse er essensen av det sosiale liv.

Ifølge Fichte er måten vi merker relasjonen til den andre på, at noe potensielt fremmedgjøres i vår egen atferd. Den andre blir et anstøt i vår egen selvforståelse. Vi får et støt utenfra, så å si, som gjør noe med måten vi relaterer oss til oss selv og den andre på. Fordi vi blir sett, må vi plutselig forholde oss til oss selv så å si via den andre. Vi blir på en måte objektivert, samtidig som objektiveringen skjer kanskje like mye innenfra vårt eget selv-forhold som utenfra. Spontant tillegger vi den andre status som en slags dommer for vår egen atferd, samtidig som vi også vurderer den andre. Møtet blir dermed en vekselvirkning mellom to prinsipielt likeverdige blikk på verden, som begge påvirker hverandre innenfra, uten egentlig å vite hva den andre tenker, føler og erfarer. Selv om dette kan oppleves ubehagelig eller utfordrende, er det for Fichte ikke et negativt anliggende. Snarere tvert imot: Fremmedgjørelsen i møtet med den andre er konstituerende for det vi mener med frihet. Tilstedeværelsen av andre mennesker tar oss ut av impulsstyrte og ikke-differensierende handlingsformer og over til mer tydeliggjort handling. Den andre blir en oppfordring til å forholde seg til ens begrensninger, og dermed også ens realistiske muligheter og ressurser.

I forlengelse av Fichtes anerkjennelsesbegrep kan vi si at bylivet i Trondheim nær sagt som alle andre større eller mindre sosiale organisasjonsformer - alltid er preget av dynamikken av hverdagslig anerkjennelse. I byen ser vi jo hverandre nær sagt hele tiden. I tillegg til den gjensidige fremmedgjøring dette innebærer, kan vi også si at vi anerkjenner hverandre mer eksplisitt gjennom å slippe hverandre forbi på fortauet, eller gjennom å veksle noen vennlige ord på butikken. Om vi dessuten også trekker inn Hegels anerkjennelsesbegrep, kan vi legge til flere nivåer av anerkjennelse, fra nivå av partnerskap, familie og vennskap til ulike nivåer av institusjonaliserte samfunnsformer (Hegel, 2009; Williams, 1992). Anerkjennelse skjer gjennom måtene tradisjon og kultur regulerer kjærlighetsliv og intimsoner, moralsk atferd og konfliktløsning, rettsvesen, borgerrettigheter og landegrenser på - kort sagt hele vår moralske væren. I likhet med Fichte har Hegel en positiv holdning til anerkjennelse som grunnleggende frigjørende. Fellesskapets organiserte anerkjennelse er det som muliggjør genuin individualitet og autonom handlingsutfoldelse.

Minneparken i Trondheim både er og er ikke som andre sosiale rom, med hensyn til de former for anerkjennelse som vi kan tenke med Fichte og Hegel. På den ene siden er vi jo de samme menneskene i parken som ellers i livet. Vi er preget av de relasjonene, forpliktelsene og mulighetene som utgjør våre liv, og dermed av de mangefasetterte former for anerkjennelse som utspiller seg i det daglige. På den annen side er det også duket for at noe skjer. Fremmedgjøringen som opptok Fichte (og som kan sies å ligge implisitt hos Bourriaud), kan for 
eksempel sies å bli potensielt forsterket med minneparkens estetiserte fremtoning. Det anstøt som andre mennesker generelt kan være for ens egen selvforståelse, blir lett aktualisert i parken gjennom at man stilles frem for andres blikk - om ikke faktisk, så i alle fall potensielt. Enda viktigere er imidlertid at de grusomme hendelsene som danner bakgrunn for parken, gir stedet et eksistensielt alvor. Mennesker ble drept, og derfor finnes dette stedet. En perseptuell ulikevekt preger dermed parken, nemlig ulikevekten gitt ved at noe mangler i det levende fellesskapet. ${ }^{5}$ For selv om vi kanskje ikke kjente noen som ble drept, direkte, så kjente vi kanskje noen som kjente noen - sønnen til en tidligere kollega, søsteren til en litt perifer studiekamerat. Og selv om vi ikke skulle ha noen slike forbindelser, husker vi antagelig TV-bildene med de dreptes ansikter. De levde, og så levde de plutselig ikke lenger. Hendelsene sitter i vår kroppslige orientering - i den fylogenetiske og ontogenetiske strukturen i våre kroppsskjemaer.

Med dette teoretiske bakteppet ser vi bedre karakteren og verdien til den hverdagsligheten som vi antydet ovenfor med Bourriaud. Midt oppi det lukkede, golde og steinaktige, og midt oppi smerten forårsaket av terroren, trer det frem en slags retningsgivende målestokk i form av perseptuelt sjikt av hverdagslighet. Parken dytter ikke en idé om et idealtypisk blikk for andre mennesker på publikum. Den oppløser heller ikke egen og andres fremmedgjøring, den omformer ikke sosial og kulturell skjevfordeling, den skyver ikke bort de alvorlige hendelsene. Likevel, som et kunstnerisk anstøt av å være et ubestemmelig men likevel artikulert estetisk uttrykk midt i byrommet, rykkes vi som publikummere potensielt ut av den mangel på stillingtaken som vi eventuelt preges av. For med den hverdagslige deltakelsen blir noe opprettet. Parken gir muligheten til å omforme ubalansen i det som skjedde 22. juli 2011, inn i nye hverdagslige handlinger, som ikke fortrenger eller skaper om det som skjedde, men som snarere kan sies å bevare og gå videre i én og samme bevegelse. Det er som om parken uttrykker: Livet går videre, og det er en god ting. Det er verdt å anerkjenne og hegne om for sin egen del.

\section{Diktene i parken. Tekstens annethet}

Vi har dermed for alvor begynt å se hvordan et etisk moment av anerkjennelse kan sies å være vevet inn i minneparkens helhetlige estetikk. Innledningsvis så vi hvordan terroren hadde utløst en kulturell selvkritikk på mange områder, som vi med Gadamer knyttet til det hermeneutiske og etiske momentet av å se seg selv i saken. På bakgrunn av det vi nå har sett, kan vi legge til at minneparken spiller dette momentet helt ut til publikum som enkeltmennesker. Å gå i minneparken er på sett og vis å møte seg selv. Man møter den man er i generell omgang med andre mennesker. Det inkluderer all den ambivalens og usikkerhet man har med seg i livet, men også en ressurs som alltid er der, nemlig evnen til å anerkjenne oss selv og andre som deler av samme menneskelige fellesskap. Denne evnen dreier seg ikke nødvendigvis om å være enig med andre, i direkte, empirisk forstand. Det dreier seg vel så mye om evnen til å godta uenighet; til å forme egen individualitet, til å la andre få forme sin, og til å gi handlingsrom til forskjeller mellom oss. Med andre ord, det dreier seg om evnen til å skape og til å håndtere et dialektisk fellesskap av divergerende meninger og livsoppfatninger, på tross av ubehaget det kan vekke. Tenkt med Fichte og Hegel er det rimelig å si at evnen til 
anerkjennelse i den forstand vi antyder her, utgjør et grunnfenomen i subjektiv og kollektiv forståelse. Når vi som kultur fortsatt har behov for å tydeliggjøre grunnlaget for en felles forståelse etter terroren 22. juli, er det dermed ikke overraskende at nettopp anerkjennelse blir tematisert og synliggjort for ens egen del.

Så langt har vi imidlertid bare tematisert anerkjennelse i sammenheng med mellommenneskelige møter. Selv om vi så temaet bli reflektert i Dragseths dikt, har vi ikke undersøkt for ens egen del det forhold at parken består av nettopp dikt. Hvilken rolle spiller diktene for den hverdagslige anerkjennelsen vi nå har begynt å tematisere? Er det å gå rundt og lese diktene i parken bare noe som foregår på siden av den generelle intersubjektive deltakelsen, eller bringer lesningen tvert imot inn en ny dybde i det vi har kalt parkens sammenveving av det etiske og det estetiske?

For å belyse spørsmålet må vi aktualisere mer av Gadamers filosofiske hermeneutikk, som jo har vært i bakgrunnen hele veien. Diktene er språkverk det er «språket om å bli sett» som utgjør Dragseths dikt. Dette er et faktum som ikke kan forbigås uten betoning, nå som Gadamers filosofi er involvert. Språk er for ham noe av det viktigste vi har - eller er - som mennesker. Språket er like viktig som luften vi puster inn, skriver Gadamer (1993b: 149). Grunnen ligger i det han belyser som språkets intersubjektive og dialektiske vesen. «Språket er [...] det universelle mediet hvor selve forståelsen fullbyrdes» (Gadamer, 2010b: 428). $\AA$ ha et språk og å ha en verden er for denne filosofen to sider av samme sak (Gadamer, 2010b: 480). I sin fulle og hele demonstrasjon rommer Gadamers språkbegrep dermed hele feltet av mellommenneskelig anerkjennelse som vi har tematisert ovenfor. Språket er grunnlaget for hele den livsverden som ble rammet 22. juli 2011, så vel som hele prosessen etterpå.

På bakgrunn av Gadamers generelle begrep om språk ser vi hvorfor nettopp dikt og diktlesning hos ham får en særlig interessant status. Dikt utgjør for Gadamer en slags transformasjon i språket - en transformasjon som aldri er ferdigstilt, og som altså skjer i intersubjektivitetens medium per se. Dikt utgjør ord som ikke forsvinner, skriver han - «Ord som egentlig først er 'der' i tilbakevendingen til dem[.]»(Gadamer, 2001b: 185). Til forskjell fra andre språklige ytringer vi utveksler i hverdagen, trer ikke diktets ord tilbake idet en mening så å si er overført. Diktets språkmaterialitet blir stående. Det utgjør en uløselig enhet av klang og mening. I kraft av denne statusen innstifter diktet en mening som ikke peker tilbake på en opprinnelig språkhendelse, men framover, mot stadig nye lesninger. Diktet blir noe mer - en slags hybrid av noe dypt fortrolig og noe dypt fremmed. Det er kjent fordi språk alltid er vårt eget språk, og fremmed fordi diktet alltid forblir et eget og selvstendig språkutrykk, uavhengig til og med av forfatterens intensjon (Gadamer, 2001b: 185).

Ovenfor la vi merke til en normativ dimensjon i Dragseths dikt. Diktet peker bakover og fremover på samme tid, mot en fremtid som må bli. Fra et hermeneutisk perspektiv er det vesentlig at dette normative momentet ikke kommer i fikserte eller fikserbare utsagn, men nettopp som dikt. Jo tettere vi går på diktet, jo mer hører vi hvordan rytmen i diktet, sammensetningen av vokaler og konsonanter, er en klanglig og melodisk understreking av det tematiske. Vi kan for eksempel høre det i denne frasen: «å bli til i det å bli sett.» Noe i det å bli sett stopper på en måte opp. Det er et melodisk anstøt som gjør oss klar over noe 
som bør aktes for sin egen del. To linjer under kommer et annet godt rytmisk og setningsmelodisk eksempel: «for vi er synlige i vår ensomhet.» Den lange $y$-en i synlige står i forhold til det mer stakkato ordet ensomhet, som for å understreke performativt spennet mellom vårt offentlige selv og den eksistensielle ensomheten som ligger i det å være et menneske. Det paradoksale, om vi tenker med Gadamer, er imidlertid at understrekingen av det ensomme skjer nettopp i det mediet som alltid binder oss sammen, altså språket. Språket er der alltid, som den bærende ordenen som gjør det mulig å elske hverandre på tross av ensomheten vi også er ovenfor hverandre (for å parafrasere Dragseth).

Interessant nok bringer diktet inn en litt annen perseptuell dimensjon enn det vi hittil har drøftet. Diktet er synlig og auditivt på samme tid. Vi kan gå omkring i parken og høre diktet i steinen. Men i hvilken forstand hører vi egentlig diktet til Dragseth? Mens flere av tekstene i parken åpenbart egner seg til høytlesning (et eksempel er utdraget fra Jens Stoltenbergs tale på Rådhusplassen i Oslo 25. juli 2011) synes det rimelig å si at Dragseths dikt ikke er egnet til det. Diktet er til stillelesning. Det er til for å høres med et slags indre øre, kan vi si med Gadamer (1993d). Det er til for å høres i en stemme som er imaginær, men som likevel er virkelig nok. For å låne et direkte sitat av Gadamer i beskrivelsen: «[A]lt ligger i den 'indre stemmen' og er der for 'det indre øret.'» (Gadamer, 1993a: 284). På den ene siden er vi i parken synlige for hverandre, og engasjerte i en felles perseptuell verden, i den forstand vi via Bourriauds relasjonelle estetikk tematiserte ovenfor. Diktet vi leser, er det samme diktet, og til forskjell fra lesning av bøker og dikt i vanlig forstand gjør vi det side om side, innenfor den smått kunstferdige konteksten. På den annen side åpner diktet et auditivt og meningsfullt rom som bare er vårt eget, midt $\mathrm{i}$ det synlige og offentlige. Diktet blir grunnleggende forskjellig i hver enkelt lesning, selv om det fremdeles er det samme diktet vi leser. Med andre ord, nettopp der vi alltid vil være avskåret fra andre - i vårt eget sinn og vår egen kropp - deltar vi i noe som allikevel er felles for alle, nemlig tekstens selvstendige annethet (Gadamer, 2010b: 273).

Igjen ser vi hvordan det etiske og estetiske henger sammen i minneparken, nå i språket og lesningen av diktene. Her er Gadamers begrep om åpenhet for tekstens annethet motstykket til det vi ovenfor tematiserte som anerkjennelse. Tenkt med Gadamer er erfaringer fra fremmedgjøring ikke et endepunkt, men snarere en begynnelse på en prosess som arbeider i retning av en harmonisering av forståelsen. «Man må miste seg selv for å finne seg selv,» skriver Gadamer (1989: 53). Poenget er eksplisitt hegeliansk: I åndens dialektiske tilbakevending til seg selv skjer utvidelsen av det individuelle i retning av det allmenne (Gadamer, 2010b: 40). Diktets annerledesværen forsvinner ikke, men blir snarere anerkjent for sin egen del ved å bli lyttet til og tatt på alvor i sitt uttrykk. Tekstens anstøt blir godtatt av leseren (Gadamer, 1989: 57). Dermed dannes også bevisstheten som godtar. Leserens forståelse vokser - både forståelsen av teksten og egenforståelse av å være en leser, en som forstår.

\section{Lesning som handling og arbeid}

La oss utdype det vi sier her. Sammen med Fichtes anerkjennelsesbegrep aktualiserte vi indirekte en radikal orientering mot handling. Fichtes historiske og sosiale subjekt kan beskrives som en tvers igjennom handlende struktur, som i visse henseender foregriper det som i dagens fenomenologi kalles enactive 
approach (Thompson, 2007). ${ }^{6}$ "Jeg'et er intet annet enn handling relatert til seg selv,» skriver Fichte (1796: 1-2n). Selvet er altså ikke et kartesiansk substrat, ikke noe enhetlig, ikke selvstendig bare i kraft av seg selv - det er ikke engang noe som handler. Det er kun handling som relaterer seg til handling. Dette handlende selvforholdet er intimt knyttet sammen med det vi sa ovenfor, om anerkjennelse. Måtene subjektet handler på, gis i samspill av anerkjennelse med andre mennesker.

Fichtes konsekvente påpeking av at det kun er som handling at noe faktisk har realitet, klinger godt med den oppfordring til politisk og sosialt engasjement som minneparken fremmer i forskjellige andre tekstutdrag. I vår kontekst blir Fichte dessuten en talsmann for en eksistensiell ansvarliggjøring av oss som subjekter, noe som kan sies å forsvinne litt i bakgrunnen med Gadamers mer generaliserte perspektiver på lesning og kunsterfaring som historiske hendelser av åpenhet.

Dersom vi nå også vender Fichtes utoverrettede handlingsorientering innover mot oss selv i form av diktlesning, ser vi hvordan lesningen eksemplifiserer ansvaret med all mulig tydelighet. For når vi leser diktene i minneparken høyt $\mathrm{i}$ våre stille sinn, er det jo kun oss selv som gjør noe, i den normale betydningen av å gjøre. ${ }^{7}$ I den grad tekstene kan sies å være ment for det indre øret, som vi sa med Gadamer, er det da også helt opp til oss å lese diktene. I motsetning til mellommenneskelig samspill som vi ellers kan inngi oss i, er det i lesesituasjonen utelukkende opp til hver enkelt av oss å realisere den muligheten som gis. Det vil si, selv om hendelsen som sådan er innskrevet i en større helhet, som verken begynner eller slutter med oss som subjekter, må det likevel til et viljens egeninitiativ. Grunnen for handling ligger ganz allein i subjektet, om vi skulle låne Fichtes uttrykk (Fichte, 1796: 35). Det som får anledning til å tydeliggjøre seg i lesningen, er dermed det vi kunne kalt et eksistensielt ansvar for egen forståelse. Ingen kan i siste omgang hjelpe oss til å utvide vår egen horisont. Vi må selv gjøre arbeidet. $^{8}$

Hegels kobling av anerkjennelse, arbeid og selvdistanse hjelper oss til å artikulere den språklig medierte handlingen det her er snakk om. Med Hegel eller rettere sagt Gadamers Hegel-lesning - kan vi kalle diktene i minneparken en form for arbeid (Gadamer, 2010b: 40). Diktene krever noe av oss, lesningen kommer ikke av seg selv. Som arbeid inkluderer lesningen tilgang til selvdistansen som Hegel assosierer med dannelse og selvbevissthet. Som arbeidende subjekter har vi ikke anledning til å handle ut fra alle tilfeldige impulser vi får i øyeblikket. En viss retning i arbeidet må bevares, samtidig som måten det handles på, likevel må tilpasses motstanden og mulighetene gitt med materialet som vi arbeider med.

Oversatt til diktlesning, og vi tenker hele tiden på dette i relasjon til diktet i parken: Som lesere handler vi ut fra diktets egenart - ikke i et utvendig forhold til diktet, men snarere innenfor språkmaterialet selv. I denne handlingserfaringen blir noe akkumulert, om vi tenker med Gadamers Hegel. "Arbeidet [...] er hemmet begjær, oppholdt forsvinnen, det vil si at det danner» (Hegel, 2009: 123, kursiv endret). Til tross for at arbeid kan være krevende - eller snarere fordi arbeidet er krevende - får noe av vital viktighet anledning til å danne seg, nemlig det Hegel kaller egensindigheten. Gjennom å danne diktet man leser, danner vi implisitt oss selv (Hegel, 2009: 123; Gadamer, 2010b: 38). Gjennom arbeidet får vi nemlig mulighet til å fordype oss i noe utenfor oss selv. ${ }^{9} \mathrm{Vi}$ praktiserer en form 
for uselvisk handling, som samtidig er en anledning til å gjenfinne en egen mening i det fremmede. Vi tilpasser oss tekstens annethet, ikke gjennom å internalisere påbud for handling utenfra, men snarere gjennom å oppdage noe innenfra egen forståelse.

Tenkt med Gadamer er det en essensiell paradigmatisk dimensjon i det vi antyder her. Diktets annethet eksemplifiserer annetheten i vårt relasjonelle liv generelt, $i$ en symbolsk eller mimetisk forstand (Gadamer, 2010b: 141 ff). De handlingsmåter som gir seg i den indre handlingen, er dermed representative for - og gjeldende i - det vi er ellers i livet også. Gjennom handlingen blir noe tydeliggjort og gjenkjent, nemlig handlingsmåter som gis i språket selv. Som lesere kan vi altså gjenoppdage noe mer i vårt eget relasjonelle grunnlag, noe som potensielt går ut over det vi visste i direkte forstand, men som likevel var i forståelsens grunnlag. Noe blir sett og erkjent i sitt vesen, kan vi si med Gadamer, og dermed også transformert inn i vår egen selvforståelse. I vår kontekst handler dette som blir erkjent, om mellommenneskelig anerkjennelse. Det normative og etiske som vi så i Dragseths dikt, blir gjennom lesningen, gjennom en gjøren, til en del av vår egen habitus. Den mellommenneskelige anerkjennelsen som diktet tematiserer, gjennom å være klang og mening, blir del av vårt eget handlingsrepertoar. Handlingsrepertoaret for hva mellommenneskelig anerkjennelse kan være, blir utvidet - innenfra sitt eget grunnlag.

Vi har nå sett hvordan et etisk moment gjennomgående er vevet sammen med det estetiske i minneparken i Trondheim. Filosofisk betraktet kan Terra Incognita sies å uttrykke en slags retningsgivende målestokk for et liv i fellesskap. Felleskapet det pekes hen imot, er som vi har sett, ikke uten potensielle forskjeller, individualitet og uenighet. Snarere tvert imot. Fellesskapet rommer forskjellighet, individualitet og uenighet - ja, det er det som gjør dette mulig. På bakgrunn av det vi har sett, kan vi også si at minneparkens sammenveving av det etiske og det estetiske er relatert til en dobbel betydning av ordet minne. Minne i betydningen hukommelse (gresk: mnéme eller latin: in memoriam) går sammen med den filosofiske betydningen gjenerindring (gresk: anamnesis) (Gadamer, 2010b: 145). Både gjennom samhandling med andre og gjennom lesning blir vi minnet på den vesentlige evnen $i$ oss til å anerkjenne, og til å ta ansvar for variasjonene i den menneskelige livsformen - eller til å la et terra incognita bli et terra cognita, ikke gjennom vold og undertrykkelse av menneskelig ekspressivitet, men snarere gjennom omsorg og bevaring. Om 22. juli dessverre lærte oss hvor galt det kan gå dersom man neglisjerer denne ressursen i oss over tid, minner parken oss på nødvendigheten av å gi den retning og artikulert forankring i oss selv.

\section{Noter}

1 Hovedrammeverket for den følgende betraktningen ligger i Gadamers filosofiske hermeneutikk (Gadamer, 2010b).

${ }^{2}$ Dette poenget av selvforståelse i saken er for øvrig gått tapt i den norske oversettelsen, se Gadamer, 2010b: 332.

${ }^{3}$ Merk at målet for det følgende ikke er eksegese, kun å anskueliggjøre fenomener relevant for minneparken. Vi ser dermed bort fra Fichtes betydning for den tyske idealismen, og det omfattende filosofiske systemet som Hegel setter sitt 
anerkjennelsesbegrep inn i. Fremstillingen av Fichte og Hegel støtter seg primært på Williams, 1992. For oversiktlig fremstilling av anerkjennelsesbegrepet i lys av politisk filosofi, se også Hverven, 2017.

${ }^{4}$ Fichte foregriper i visse henseender det Merleau-Ponty utvikler som "existential mimesis" (Merleau-Ponty, 2011, 2012). Interessant nok mangler imidlertid Merleau-Ponty et utviklet begrep om anerkjennelse, i hvert fall i den elaborerte formen som Hegel tilbyr.

${ }^{5}$ Ulikevekt - eller ekvilibrium - hentes løst fra Gadamer, 2010c og Hegel, 2009. For detaljerte beskrivelser av hvordan liv og ekvilibrium henger sammen i atferd, se også Merleau-Ponty, 2011. Se også Solli, 2016 kap. 16, for drøfting av hvordan begrepet kan forstås i krysningen mellom fenomenologiske og hermeneutiske tilnærminger til erfaring.

${ }^{6}$ Her går vi i praksis ut over det Gadamer selv tematiserer. Selv om handling kan sies å være implisert i Gadamers begrep om Vollzug, utarbeider han ikke selv noe detaljert begrep om handling. I den sene Gadamers interesse for Inneres hõren kan man imidlertid se en bevegelse mot handlingsaspektet i erfaringen. Se Gadamer, 1993d; Solli, 2016

7 Tenkt med Gadamer har teksten sin egen måte å virke på, sin energeia (Gadamer, 2010b: 41). Det vi imidlertid forsøker å synliggjøre, er den subjektive egenaktiviteten av å lese. Dette er inkludert i Gadamers begrep på et kategorialt nivå, men forsvinner likevel ut som noe tematisert for sin egen del. Se sluttnote 6 over.

${ }^{8}$ Selv om Fichte bestreber seg på å situere det kantianske subjektet, er det ofte blitt påpekt at han likevel havner $\mathrm{i}$ en uheldig subjekt-objekt-dikotomi. Anerkjennelse blir i siste omgang noe som gjøres mellom to atomistiske størrelser (Williams, 1992: $49 \mathrm{ff}$ ).

${ }^{9}$ I bakgrunnen for det vi skriver her ut i fra anerkjennelsesbegrepet, er også Hegels betoning av kjærlighetens vesen og viktighet. (Hegel, 1986; Williams, 1992: $180 \mathrm{ff}$ )

\section{Referanser}

Bangstad, S. (2014). Anders Breivik and the Rise of Islamophobia. London: Zed Books.

Borchgrevink, A. S. (2012). En norsk tragedie: Anders Behring Breivik og veiene til Utøya. Oslo: Gyldendal.

Bourriaud, N. (2007). Relasjonell estetikk. Oslo: Pax forlag.

Breivik, J. (2014). Min skyld? Oslo: Juritzen forlag.

Christensen, M. (2013). Moren: historien om Wenche Behring Breivik. Oslo: Aschehoug.

Fichte, J. G. (1796). Grundlage des Naturrechts nach Principien der Wissenschaftslehre. Jena: Christian Ernst Gabler.

Gadamer, H.-G. (1989). Reply to Jacques Derrida. I D. P. Michelfelder \& R. E. Plamer (Red.), Dialogue and Deconstruction. New York: State University of New York Press.

Gadamer, H.-G. (1993a). Lesen ist wie Übersetzen (1989). I Ästhetik und Poetik I: Kunst als Aussage. Tübingen: Mohr/Siebeck. 
Gadamer, H.-G. (1993b). Mensch und Sprache (1966). I Hermeneutik II: Wahrheit und Methode; Ergänzungen; Register. Tübingen: Mohr/Siebeck.

Gadamer, H.-G. (1993c). Philosophie und Literatur (1981). I Ästhetik und Poetik I: Kunst als Aussage. Tübingen: Mohr/Siebeck.

Gadamer, H.-G. (1993d). Ästhetik und Poetik II: Ästhetik im Vollzug. Tübingen: Mohr/Siebeck.

Gadamer, H.-G. (2001a). Estetikk og hermeneutikk. I S. Lægreid \& T. Skorgen (Red.), Hermeneutisk lesebok. Oslo: Spartacus.

Gadamer, H.-G. (2001b). Tekst og fortolkning. I S. Lægreid \& T. Skorgen (Red.), Hermeneutisk lesebok. Oslo: Spartacus.

Gadamer, H.-G. (2003). Om forståelsens sirkel. I Forståelsens filosofi. Oslo: Cappelen Akademiske forlag.

Gadamer, H.-G. (2010a). Hermeneutik I: Wahrheit und Methode: Grundzüge einer philosophischen Hermeneutik. Tübingen: Mohr/Siebeck.

Gadamer, H.-G. (2010b). Sannhet og metode. Oslo: Pax forlag.

Gadamer, H.-G. (2010c). Über die Verborgenheit der Gesundheit: Aufsätze und Vorträge. Frankfurt am Main: Suhrkamp Verlag.

Gjørv, A. B. 1. (2012). Rapport fra 22. juli kommisjonen. Oppnevnt ved kongelig resolusjon 12. august for à trekke loerdom fra angrepene på regjeringskvartalet og Utøya 22. juli 2011. Oslo: Nou.

Harr, A. G. G., \& Partapuoli, K. H. (2012). Om trakassering av muslimer og innvandrere etter eksplosjonen i Regjeringskvartalet 22.07.2011. Oslo: Antirasistisk senter.

Hegel, G. W. F. (1986). Entwürfe über die Religion und Liebe. I Hegel Werke, Theorie Werksgabe. Frankfurt am Main: Suhrkamp Verlag.

Hegel, G. W. F. (2009). Åndens fenomenologi. Oslo: Pax forlag.

Heggren, S. M. (2017). Kunsten å erindre et nasjonalt traume. Estetikk og konflikt bak minnestedet Memory Wound. Bergen: UiB.

Hverven, S. (2017). Ingen mennesker er født frie. I M. Kristjánsson, O. Innset, S. Hverven, \& O. Dybedahl (Red.), Ingen mennesker er født frie. Oslo: Dreyers forlag.

Merleau-Ponty, M. (2011). The Structure of Behavior. Pittsburgh: Duquesne University Press.

Merleau-Ponty, M. (2012). Phenomenology of Perception. London: Routledge.

Mortensen, J. 1. (2013). Kunstplan for Minnesteder etter 22. juli. Oslo: Kulturdepartementet.

Seierstad, Å. (2013). En av oss: En fortelling om Norge. Oslo: Kagge.

Solli, M. (2016). Towards an Embodied Hermeneutics; Gadamer, Merleau-Ponty, and Nondirective Meditation. Trondheim: NTNU

Thompson, E. (2007). Mind in Life. Cambridge: The Belknap Press of Harvard University.

Vetlesen, A. J. (2014). Studier i ondskap. Oslo: Universitetsforlaget.

Williams, R. R. (1992). Recognition: Fichte and Hegel on the Other. State University of New York, Albany: State University of New York Press. 